Published in final edited form as:

Nat Immunol. 2008 January ; 9(1): 25-33. doi:10.1038/ni1544.

\title{
Unique functions of the type II interleukin 4 receptor identified in mice lacking the interleukin 13 receptor $\alpha 1$ chain
}

\author{
Thirumalai R Ramalingam ${ }^{1}$, John T Pesce ${ }^{1}$, Faruk Sheikh ${ }^{2}$, Allen W Cheever ${ }^{3}$, Margaret M \\ Mentink-Kane ${ }^{1}$, Mark S Wilson ${ }^{1}$, Sean Stevens ${ }^{4}$, David M Valenzuela ${ }^{4}$, Andrew J Murphy ${ }^{4}$, \\ George D Yancopoulos ${ }^{4}$, Joseph F Urban Jr ${ }^{5}$, Raymond P Donnelly ${ }^{2}$, and Thomas A \\ Wynn ${ }^{1}$ \\ 1 Laboratory of Parasitic Diseases, National institutes of Allergy and Infectious Diseases, Bethesda, Maryland \\ 20892, USA. \\ 2Division of Therapeutic Proteins, Center for Drug Evaluation and Research, Food and Drug Administration, \\ Bethesda, Maryland 20892, USA.
}

3Biomedical Research Institute, Rockville, Maryland 20852, USA.

4Regeneron Pharmaceuticals, Tarrytown, New York 10591, USA.

5Diet, Genomics, and Immunology Laboratory, Beltsville Human Nutrition Research Center, Agricultural Research Service, United States Department of Agriculture, Beltsville, Maryland 20705, USA.

\section{Abstract}

The interleukin 4 receptor (IL-4R) is a central mediator of T helper type $2\left(\mathrm{~T}_{\mathrm{H}} 2\right)$-mediated disease and associates with either the common $\gamma$-chain to form the type I IL-4R or with the IL-13R $\alpha 1$ chain (IL-13R $\alpha 1$ ) to form the type II IL-4R. Here we used Ill3 $\mathrm{ral}^{-/-}$mice to characterize the distinct functions of type I and type II IL-4 receptors in vivo. In contrast to $I l 4 \mathrm{ra}^{-1-}$ mice, which have weak $\mathrm{T}_{\mathrm{H}} 2$ responses, $I l 13 \mathrm{ral}^{-/-}$mice had exacerbated $\mathrm{T}_{\mathrm{H}} 2$ responses. ${ }^{\text {Ill3ral-I- }}$ mice showed much less mortality after infection with Schistosoma mansoni and much more susceptibility to Nippostrongylus brasiliensis. IL-13R $\alpha 1$ was essential for allergen-induced airway hyperreactivity and mucus hypersecretion but not for fibroblast or alternative macrophage activation. Thus, type I and II IL-4 receptors exert distinct effects on immune responses.

Interleukin 4 (IL-4) and IL-13 are T helper type $2\left(\mathrm{~T}_{\mathrm{H}} 2\right)$ cytokines with pleiotropic functions in immunity. They mediate resistance to many gastrointestinal parasites ${ }^{1}$ and promote allergic inflammation $^{2,3}$, asthma ${ }^{4}$ and fibrosis ${ }^{5}$. IL-4 and IL-13 exert a wide range of effects on many cell types, including macrophages, fibroblasts, eosinophils, mast cells, natural killer cells, B cells and T cells ${ }^{6}$. IL-4 and IL-13 bind to and send signals through receptors composed of various combinations of four receptor subunits: IL-4R $\alpha$, IL-13R $\alpha 1$, IL-13R $\alpha 2$ and the common

\footnotetext{
(C) 2007 Nature Publishing Group

Correspondence should be addressed to T.A.W. (E-mail: twynn@ niaid.nih.gov). AUTHOR CONTRIBUTIONS

T.R.R. designed and did experiments and contributed to the manuscript; J.T.P., F.S., M.M.M.-K. and M.S.W. designed and did experiments; A.W.C. and J.F.U. assisted in animal experiments, scoring and data analysis; S.S., D.M.V., A.J.M. and G.D.Y. provided the $I l 13 \mathrm{ral}^{-1-}$ mice and assisted in writing the manuscript; R.P.D. designed and assisted in experiments; and T.A.W. designed and supervised the project, designed and assisted in experiments, and helped write the manuscript.

COMPETING INTERESTS STATEMENT

The authors declare competing financial interests: details accompany the full-text HTML version of the paper at http://www.nature.com/natureimmunology/.

Reprints and permissions information is available online at http://npg.nature.com/reprintsandpermissions
} 
$\gamma$-chain. The type I IL-4 receptor, a heterodimer of IL-4R $\alpha$ and the common $\gamma$-chain, mediates IL-4-dependent activation of the transcription factor STAT6 in hematopoietic cells and is thus mostly responsible for the population expansion of $\mathrm{CD}^{+} \mathrm{T}_{\mathrm{H}} 2$ cells. The type II IL-4 receptor, a heterodimer of IL-4R $\alpha$ and IL-13R $\alpha 1$ chains, can bind both IL- 4 and IL-13 and is thought to be the main route by which nonhematopoietic cells respond to these cytokines ${ }^{7}$. Finally, the IL-13R $\alpha 2$ chain binds IL-13 with high affinity and functions as a 'decoy receptor' 8 , although a report has suggested it can also show STAT6-independent signaling activity?.

Because IL-4R $\alpha$ functions as subunit of receptors binding both IL-4 and IL-13, it is the most widely studied of the four receptor subunits. However, although it is now apparent that IL-4R $\alpha$ is central to the pathogenesis of a wide variety of $\mathrm{T}_{\mathrm{H}} 2$-associated diseases, thus far it has been impossible to assign the various functions of IL-4R $\alpha$ to the type I or type II IL-4R signaling pathway, because both receptor complexes are absent from IL-4R $\alpha$-deficient mice. Therefore, to elucidate the physiological function of the type II receptor, we generated mice with targeted deletion of Ill3ral. We used in vitro studies to assess the function of the type II IL-4R in the development of alternatively activated macrophages (AAM $\phi \mathrm{s}$ ) and in the activation of fibroblasts. Our in vivo studies focused on the function of the type II IL-4R after infection with the $\mathrm{T}_{\mathrm{H}} 2$-inducing pathogens Schistosoma mansoni and Nippostrongylus brasiliensis and in an experimental model of asthma. We found that in contrast to IL-4R $\alpha$, IL-13R $\alpha 1$ was not required for AAM $\phi$ development. $I l 13 \mathrm{ral}^{-1-}$ mice also developed stronger $\mathrm{CD}^{+} \mathrm{T}_{\mathrm{H}} 2$ responses. However, $I l 13 \mathrm{ral}^{-1-}$ mice showed less morbidity and mortality after $S$. mansoni infection and failed to expel $N$. brasiliensis from the gut. In addition, airway hyperreactivity and mucus production were completely abrogated after intratracheal administration of a $\mathrm{T}_{\mathrm{H}}$ 2-inducing allergen in $I l 13 \mathrm{ral}^{-l-}$ mice. Thus, our studies elucidate the unique functions of the type I and type II IL-4R signaling pathways in the development of $\mathrm{T}_{\mathrm{H}} 2$ immune responses.

\section{RESULTS}

\section{Generation of $/ 113 \mathrm{ra1}^{-/-}$mice}

We used VelociGene technology 10 to create a targeting vector in which exon 2 (except for its first 17 nucleotides) through exon 4 were replaced with the transmembrane lac $Z$ reporter gene and a loxP-flanked neomycin selection cassette (Supplementary Fig. 1a online). We assigned scores for correct gene targeting in $\mathrm{F}_{1} \mathrm{H}_{4}(\mathrm{C} 57 \mathrm{BL} / 6 \times 129$ hybrid) embryonic stem cell clones by the loss-of-native- allele assay 10 and determined the genotypes of $1113 \mathrm{ral}^{+/+}, \mathrm{Ill}_{3} \mathrm{ral}^{+/-}$ and $I l 13 \mathrm{ral}^{-1-}$ offspring by PCR analysis (Supplementary Fig. 1b). $\mathrm{Ill}_{3} \mathrm{ral}^{-1-}$ mice were healthy and fertile and manifested no physical impairment. Naive $1113 \mathrm{ral}^{-1-}$ mice showed no fundamental anomalies in the lymphoid compartment; thymi, lymph nodes and spleens were

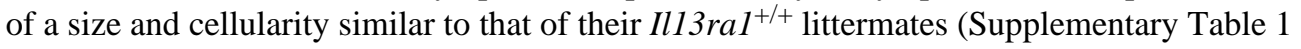
online). $\mathrm{CD} 4^{+}, \mathrm{CD}^{+}$and $\mathrm{CD} 4^{+} \mathrm{CD} 8^{+}$populations were present at the expected frequencies in the thymus (Fig. 1). B cells, $\mathrm{CD} 4^{+}$and $\mathrm{CD} 8^{+} \mathrm{T}$ cells, and natural killer cells were also present in wild-type proportions and numbers in the spleen and lymph nodes.

\section{IL-13Ra1 in macrophage and fibroblast activation}

Alternative macrophage activation is regulated by an IL-4R $\alpha-$ STAT6- dependent mechanism 11 ; however, the function of type I versus type II IL-4R signaling in the development of classically and alternatively activated macrophages has remained unclear. To elucidate the contribution of the type II IL-4R, we generated bone marrow-derived

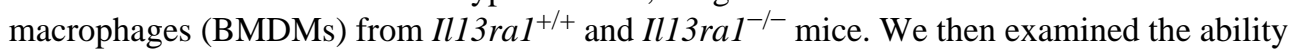
of IL-4 and IL-13 to regulate a variety of responses, including phosphorylation of STAT6, expression of STAT6-regulated genes (Chi3l3 and Arg 1), elaboration of arginase activity, and interferon- $\gamma($ IFN- $\gamma)$-induced nitric oxide production. 
As expected, both IL-4 and IL-13 stimulated STAT6 phosphorylation in $1113 \mathrm{ral}^{+/+}$BMDMs (Fig. 2a). In contrast, IL-4 but not IL-13 triggered STAT6 phosphorylation in $1113 \mathrm{ral}^{-/-}$ BMDMs. Ill3 $\mathrm{ral}^{-1-}$ mice showed no IL-13-induced increase in Chi3l3 or Arg1 mRNA (Fig. $2 b$ ) and, unlike $1 l 13 \mathrm{ral}^{+/+}$BMDMs, did not show substantial arginase activity after IL-13 simulation (Fig. 2c). We obtained similar results with thioglycollate-elicited macrophages,

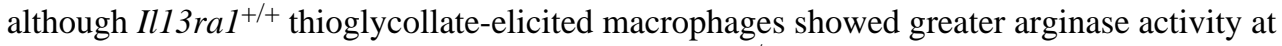
baseline and after IL-13 stimulation than did $I l 13 \mathrm{ral}^{+/+}$BMDMs (Fig. 2d). Finally, IL-13 potently inhibited IFN- $\gamma$-induced nitric oxide production (classical macrophage activation) in Ill $3 \mathrm{raI}^{+/+}$macrophages but had no effect on nitric oxide production by $\mathrm{Ill} 3 \mathrm{ral}^{-1-}$

macrophages, even at very high concentrations (Fig. 2e). However, in contrast to IL-13, IL-4 exerted similar effects on $\mathrm{Ill}_{3} \mathrm{ral}^{+/+}$and $\mathrm{Ill}_{\mathrm{ral}}{ }^{-/-}$macrophages.

IL-4 and IL-13 also regulate the function of nonhematopoietic mesenchymal cells, including fibroblasts ${ }^{12}$. Nevertheless, it has remained unclear whether IL-4 and IL-13 exploit mainly type I or type II IL-4R signaling pathways in fibroblast activation $7,13,14$. To address this, we generated primary fibroblasts from $\mathrm{Ill} 3 \mathrm{ral}^{+/+}$and $\mathrm{Ill} 3 \mathrm{ral}^{-l_{-}}$mice and monitored STAT6 phosphorylation and STAT6-dependent gene expression (Chi3l3, Retnla and Il13ra2) after stimulating the cells with IL-4 and IL-13. As expected, we found no detectable Ill3ral message in $I l 13 \mathrm{raI}^{-/}$fibroblasts. In contrast, transcripts encoding the common $\gamma$-chain (Il2 $\mathrm{rg}$ ) and IL-4R $\alpha$ were readily detectable in the mutant cells; $I l 13 \mathrm{ral}^{+/+}$fibroblasts expressed transcripts encoding all three receptor subunits (Supplementary Fig. 2a online). Expression of the common $\gamma$-chain by nonhematopoietic cells, although unexpected, has been shown before in myofibroblasts ${ }^{14}$ and human bronchial epithelial cells ${ }^{15}$. Consistent with those findings, there was IL-13-induced STAT6 phosphorylation in $1 / 13 \mathrm{ral}^{+/+}$but not $1 / 13 \mathrm{ral}^{-/-}$fibroblasts (Supplementary Fig. 2b). The considerable increase in expression of Chi3l3, Retnla and Ill3ra2 mRNA in IL-13-stimulated $\mathrm{Ill}_{3} \mathrm{ral}^{+/+}$fibroblasts was also abolished in $\mathrm{Ill} 3 \mathrm{ral}^{-/-}$ fibroblasts, thus confirming the functional ablation of type II IL-4R signaling (Supplementary Fig. 2c). In contrast, IL-4 stimulated robust STAT6 phosphorylation and induction of Chi3l3 and Retnla mRNA in $I l 13 \mathrm{ral}^{+/+}$and $I l 13 \mathrm{ral}^{-/-}$fibroblasts. Notably, we found consistently less IL-4-induced $I l 13 \mathrm{ra} 2 \mathrm{mRNA}$ expression in the $1113 \mathrm{ral}^{-1-}$ fibroblasts, which suggested that at least a subset of IL-4-inducible genes depend on type II IL-4R signaling for optimal induction (Supplementary Fig. 2c). In contrast to Ill3ra2 expression, expression of genes encoding the other receptor subunits was not substantially regulated by IL-4 or IL-13 (Supplementary Fig. 2d). Thus, the type II IL-4R signaling pathway was functionally disabled in $1 l 13 \mathrm{ral}^{-1-}$ mice and was dispensable for fibroblast and alternative macrophage activation.

\section{IL-13Ra1 in S. mansoni-induced $\mathrm{T}_{\mathrm{H}} 2$ responses}

In addition to modulating the activation of macrophages and fibroblasts, IL-4 and IL-13 regulate $B$ cell proliferation and survival and antibody class switching 16,17 . To elucidate the function of the type II IL-4R in B cells, we infected $I l 13 \mathrm{ral}^{+/+}$and $I l 13 \mathrm{ral}^{-/-}$mice with $S$. mansoni and assessed the parasite-specific antibody response in acutely infected mice (8-9 weeks) and chronically infected mice (12 weeks). Unexpectedly, although IL-13 has been postulated to promote $\mathrm{B}$ cell survival and antibody class switching ${ }^{18}$, in general, the infected Ill3ral $I^{+/+}$and $\mathrm{Ill}_{3} \mathrm{raI}^{-/-}$mice developed similar antibody responses (Fig. 3). In fact, $1 l 13 \mathrm{ral}^{-1-}$ mice had more immunoglobulin A (IgA) at week 8 and slightly more IgG1 and IgG3 at week 12. IgE was the only isotype that was much lower in $I l 13 \mathrm{ral}^{-1-}$ serum, but this defect was restricted to chronically infected mice. Thus, type II IL-4R signaling is minimally involved in the development of humoral responses after infection with S. mansoni.

Although it is well known that IL-4 functions as the main inducer of $\mathrm{CD}^{+} \mathrm{T}_{\mathrm{H}} 2$ cell responses, the function of IL-13 in the development of $\mathrm{T}_{\mathrm{H}} 2$ responses is controversial $16,19,20$. Although IL-13 receptors are not expressed on $\mathrm{T}$ cells 21 , many studies with $I l 13^{-1-}$ mice have suggested 
that IL-13 has a critical albeit indirect function in the development of $\mathrm{T}_{\mathrm{H}} 2$ cell-mediated responses in vivo ${ }^{20}$. However, disruptions in 1113 can affect expression of the closely linked Il4 gene, perhaps complicating the conclusions of such studies ${ }^{19}$. Because the type II IL-4R functions as the main signaling receptor for IL-13, $\mathrm{Ill3ral}^{-1-}$ mice provide an ideal tool for investigating the function of IL-13 and, more specifically, the contribution of type II IL-4Rmediated signaling in $\mathrm{T}_{\mathrm{H}} 2$ responses in vivo.

We infected mice with $S$. mansoni cercariae and examined liver lymphocyte production of IL-4, IL-5, IL-13 and IFN- $\gamma$ ex vivo by intracellular cytokine staining at 9 and 12 weeks after infection. As expected, we detected many IL-4-, IL-5- and IL-13-producing CD4 ${ }^{+} \mathrm{T}$ cells in Ill3 $\mathrm{ral}^{+/+}$livers at 9 weeks after infection (Fig. 4). However, the percentage of $\mathrm{T}_{\mathrm{H}} 2$ cytokineproducing $\mathrm{CD}^{+} \mathrm{T}$ cells was significantly higher in $1113 \mathrm{ral}^{-1-}$ livers at both the acute and chronic time points. These data suggest that IL-13R $\alpha 1$ exerts a negative effect on $\mathrm{T}_{\mathrm{H}^{2}} 2$ response development in vivo, in contrast to its $\mathrm{T}_{\mathrm{H}^{2}}$-skewing effect on neonatal $\mathrm{CD}^{+}{ }^{+}$cells ${ }^{22}$. Notably, we found no change in the number of IFN- $\gamma$-producing $\mathrm{CD}^{+} \mathrm{T}$ cells at week 9 and a small but consistent increase at week 12 in $I l 13 \mathrm{ral}^{-1-}$ mice (Fig. 4). Thus, the greater frequency of $\mathrm{CD}^{+} \mathrm{T}_{\mathrm{H}} 2$ cells did not result from a diminished counter-regulatory $\mathrm{T}_{\mathrm{H}} 1$ response. These data were reproducible on both the BALB/c and C57BL/6 genetic backgrounds (data not shown).

\section{IL-13Ra1 in schistosomiasis}

Next we examined the granulomatous response in the liver at 9 and 12 weeks after infection. In general, we noted no considerable differences in granuloma development in the Ill3 $\mathrm{ral}^{+/+}$and $I l 13 \mathrm{ral}^{-/-}$mice at any time point, suggesting that type II IL-4R signaling has little effect on the overall inflammatory response (Fig. 5a). However, we noted a modestly higher frequency of eosinophils in granulomatous lesions in $\mathrm{IlI3ral}^{-1-}$ mice (Fig. 5b), which was consistent with the higher IL-5 production in these mice (Fig. 4). Nevertheless, despite their wild-type inflammatory response, the development of hepatic fibrosis in the $I l 13 \mathrm{ral}^{-/-}$ mice was significantly lower at both the acute and chronic time points (Fig. 5c). Notably, the attenuated fibrotic response was not attributed to differences in parasite burden (Supplementary Table 2 online).

To explore the mechanisms by which IL-13R $\alpha 1$ regulates the pathogenesis of schistosomiasis, we isolated liver RNA at 9 and 12 weeks after infection and used real-time PCR to quantify the expression of genes associated with $\mathrm{T}_{\mathrm{H}} 2$ responses (Fig. 6a), alternative macrophage activation (Fig. 6b) and extracellular matrix deposition (Fig. 6c). In agreement with the intracellular cytokine staining data, $I l 13 \mathrm{ral}^{-1-}$ mice had much higher expression of transcripts encoding IL-13, IL-4 and IL-10; these findings confirmed the conclusion that the type II IL-4R functions as a negative regulator of $\mathrm{T}_{\mathrm{H}} 2$ responses in vivo (Fig. 6a). We also noted much greater abundance of transcripts encoding tumor necrosis factor and near ablation of expression of eotaxin 1 (Ccll1) mRNA in $I l 13 \mathrm{ral}^{-/}$mice, which suggested that type II IL-4R signaling regulates several distinct cytokine signals in the liver.

However, in contrast to the influence of IL-13R $\alpha 1$ deficiency on the $\mathrm{T}_{\mathrm{H}} 2$ response, we found no evidence that IL-13R $\alpha 1$ regulated the expression of genes that characterize AAM $\phi$ development in vivo (Fig. 6b), consistent with our in vitro functional studies with BMDMs (Fig. 2). Indeed, expression of genes encoding the mannose receptor, YM1, FIZZ1, AMCase and inducible nitric oxide synthase were significantly higher in $I l 13 \mathrm{ral}^{+/+}$and $\mathrm{Il13} \mathrm{ral}^{-/-}$livers after infection. Thus, IL-13R $\alpha 1$ is not critically involved in alternative macrophage activation in vivo.

Finally, we monitored the expression of several matrix-associated genes, including those encoding transforming growth factor- $\beta 1(T g f b 1)$, matrix metalloproteinase $9(\mathrm{Mmp} 9)$ and procollagen VI (Col6al), which are all induced in the liver after $S$. mansoni infection 8,23 . 
Consistent with the diminished fibrosis, Col6al expression was much lower in $1113 \mathrm{ral}^{-1-}$ livers (Fig. 6c). In contrast, expression of $T g f b 1$ and $M m p 9$ was much higher in $1 l 13 \mathrm{ral}^{-1-}$ livers, particularly in the chronically infected mice. Thus, activation of the profibrotic cytokine TGF$\beta 1$ by MMP9 could have contributed to the residual increase in fibrosis noted in the Ill3ral ${ }^{-1-}$ mice.

Because the construction of the $I l 13 \mathrm{ral}^{-/-}$mouse included an in-frame insertion of a lacZ reporter gene, we measured $\beta$-galactosidase activity as a surrogate of $I l 13 \mathrm{ral}$ expression. We detected $\beta$-galactosidase activity in the villi, muscularis mucosae and muscularis externa of the gut in naive mice (Supplementary Fig. 3 online). However, the pattern of $\beta$-galactosidase expression in the gut changed very little after $S$. mansoni infection. In contrast, we noted little $\beta$-galactosidase activity in the liver before infection, although when we viewed sections under high power, we detected modest staining along the epithelial lining of the biliary tracts (Supplementary Fig. 3). Nevertheless, $\beta$-galactosidase expression was much higher in the liver after infection, with substantial staining concentrated in fibroblast-dense areas surrounding the granulomas.

\section{Lower mortality in $/ / 13 \mathrm{ra1}^{-/-}$mice}

We did survival studies with the $S$. mansoni model to determine the consequences of type II IL-4R deficiency during a chronic $\mathrm{T}_{\mathrm{H}} 2$-driven inflammatory response. We included mice lacking both IL-4 and IL-13 (double-knockout mice) as controls, as published studies have shown that mice with deficiencies in both type I and type II IL-4R signaling pathways are highly susceptible to $S$. mansoni infection $24-27$. As expected, by week 10 , over $75 \%$ of the double-knockout mice succumbed to infection (Fig. 7a). In contrast, the wild-type group showed only $50 \%$ mortality by week 18 . However, over $80 \%$ of the $1113 \mathrm{ral}^{-1-}$ mice survived through week 22, demonstrating that the type II IL-4R was highly pathogenic during $S$. mansoni infection. The enhanced survival of the chronically infected $\mathrm{Ill} 3 \mathrm{ral}^{-1-}$ mice was also associated with much less liver fibrosis, as determined by hydroxyproline assay (Fig. 7b) and by microscopy (Fig. 7c). In addition, markers of hepatocellular damage and biliary obstruction (alanine aminotransferase, aspartate aminotransferase and alkaline phosphatase) were also

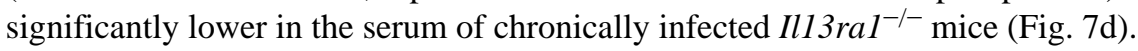

\section{IL-13Ra1 deficiency impairs the expulsion of $N$. brasiliensis}

To determine whether the type II IL-4R was critical for the development of immunity in the gut, we also infected $I l 13 \mathrm{ral}^{-/-}$mice with the gastrointestinal nematode parasite $N$. brasiliensis. In this model, infective-stage larvae are injected subcutaneously, immature parasites transit through the lungs, and adult parasites mature in the jejunum 5-6 d after infection. Immunity to $N$. brasiliensis depends on IL-4R and STAT6 (ref. 28), and although IL-13 seems to be more important than IL-4 (ref. 28), exogenous treatment with IL-4 can induce expulsion in the absence of IL-13 (ref. 1). Ex vivo intracellular cytokine staining of mesenteric lymph node cells $12 \mathrm{~d}$ after infection showed that $1 / 13 \mathrm{ral}^{-1-}$ mice had twofold more IL-5-and IL-13-producing $\mathrm{CD}^{+}$cells than did their $\mathrm{Ill} \mathrm{ral}^{+/+}$littermates (Fig. 8a). However, despite showing stronger $\mathrm{T}_{\mathrm{H}} 2$ responses, $I l 13 \mathrm{ral}^{-/-}$mice failed to expel the parasites, emphasizing the importance of the type II IL-4R in this process (Fig. 8b).

\section{IL-13Ra1 is required for allergic airway hyperreactivity}

Finally, we examined the function of the type II IL-4R in a mouse model of asthma ${ }^{29}$. $1 l 13 \mathrm{ral}^{+/+}$mice primed and challenged intratracheally with $S$. mansoni egg antigen (SEA), a strong $\mathrm{T}_{\mathrm{H}} 2$ stimulus, developed robust $\mathrm{T}_{\mathrm{H}} 2$ responses in the lungs, as shown by quantitative PCR analysis of cytokine gene expression (Fig. 9a). However, as noted in the infection studies, Ill3 $\mathrm{ral}^{-1-}$ mice developed enhanced lung $\mathrm{T}_{\mathrm{H}} 2$ responses. Ill $3 \mathrm{ral}^{-1-}$ mice showed no defect in induction of Argl expression (Fig. 9a), a marker of alternative macrophage activation; this 
finding suggests that the type II IL-4R is not critical for the development of Arg1-expressing cells in the lung, in agreement with the $S$. mansoni infection studies (Fig. 6b). Furthermore, analysis of bronchoalveolar lavage fluid suggested that IL-13R $\alpha 1$ had little effect on the inflammatory response (Fig. 9b), although close examination of lung histology indicated that there were fewer eosinophils and more macrophages in the lungs of $1 \mathrm{ll} 3 \mathrm{ral}^{-l-}$ mice (Fig. 9c).

Nevertheless, despite developing substantial inflammation and stronger $\mathrm{T}_{\mathrm{H}} 2$ responses, Ill $3 \mathrm{ral}^{-1-}$ mice showed little to no increase in the expression of several important asthmaassociated genes, including Ccl11, Clca3 and Muc5ac (Fig. 9a). IgE titers were also much lower in the serum of SEA-challenged $I l 13 \mathrm{ral}^{-1-}$ mice (Fig. 9d). Most notable, however, was the complete absence of airway hyper-reactivity (Fig. 9e) and mucus hypersecretion (Fig. 9f,g) in Ill3 $\mathrm{ral}^{-/-}$mice, which indicated that the type II IL-4R was critically required for the development of allergic airway disease.

\section{DISCUSSION}

Although genetically modified mice have been generated to investigate IL-4 and IL- 13 effector functions in vivo, none of the experiments with suchmice have differentiated the unique contributions of the type I and type II IL-4 receptors. IL-4R $\alpha$-deficient mice show defects in both type I and type II IL-4R signaling and thus are similar to mice lacking both IL-4 and IL-13 (refs. 30,31 ) in that they are both incapable of activating STAT6. Because IL-4 interacts with both types of IL-4R complexes, both type I and type II IL-4R signaling pathways are impaired in IL-4- deficient mice ${ }^{32}$. Finally, although IL-13 signals exclusively through the type II IL-4R complex, the remaining IL-4 response in IL-13-deficient mice can signal through both type 1 and type II IL-4 receptors ${ }^{30}$. Therefore, disrupting IL-13R $\alpha 1$ expression has proven to be the best strategy for characterizing the unique functions of the type II IL-4R.

In vitro experiments with both hematopoietic (BMDM) and nonhematopoietic (primary fibroblast) cell types confirmed that $I l 13 \mathrm{ral}^{-/-}$mice were unresponsive to IL-13. Whereas published studies have suggested that IL-13 is critically involved in the development of $\mathrm{CD}^{+} \mathrm{T}_{\mathrm{H}} 2$ cell responses in vivo 20,33 , our experiments suggested the opposite. Indeed, Ill $3 \mathrm{ral}^{-1-}$ mice developed stronger $\mathrm{T}_{\mathrm{H}} 2$ responses in all three experimental disease models examined, suggesting that IL-13R $\alpha 1$ 'antagonizes' $\mathrm{CD} 4{ }^{+} \mathrm{T}_{\mathrm{H}} 2$ cell development in vivo. These results were somewhat unexpected, because IL-13 activity is abrogated in both IL-13-deficient and IL-13R $\alpha 1$-deficient mice. However, disruption of $I l 13$ diminished transcription of the closely linked $I l 4$ gene ${ }^{19}$.

Therefore, IL-13-deficient mice are to some extent also deficient in IL-4. The lower production of IL-4 probably explains why CD4 ${ }^{+} \mathrm{T}_{\mathrm{H}} 2$ cell development is impaired in IL-13-deficient mice. Our results have shown that type II IL-4R-dependent signaling suppressed $\mathrm{T}_{\mathrm{H}} 2$ cytokine responses. Because type I and type II IL-4 receptors compete for IL-4, the absence of the type II IL-4R complex may yield more free IL-4 to bind the type I IL-4R expressed on T cells. This may explain why $\mathrm{CD}^{+} \mathrm{T}_{\mathrm{H}} 2$ cell development is enhanced in the absence of IL-13R $\alpha 1$. However, a quantitative trait locus in a region of 129 DNA closely linked to IL-13R $\alpha 1$ might also contribute to this.

IL-13 also activates human B cells, augments antibody production and regulates IgE antibody class switching 21,34,35. Although mouse B cells were originally reported to be unresponsive to IL-13 (ref. 16), it has been shown that IL-13 can enhance antibody production in mice by increasing B cell survival ${ }^{17}$. IL-13-transgenic mice are also capable of developing IgE responses in the absence of IL-4 (ref. 36). Because their $\mathrm{T}_{\mathrm{H}} 2$ response remains intact,

Ill $3 \mathrm{ral}^{-1-}$ mice provide an ideal tool for investigating the function of type II IL-4R signaling in B cell development and antibody class switching in vivo. In general, our data indicated that 
the type II IL-4R had little to no influence on IgG production after infection. The only substantial difference noted in the $I l 13 \mathrm{ral}^{-1-}$ mice was lower serum IgE titers in mice chronically infected with $S$. mansoni, a finding recapitulated in our asthma studies. These data suggest that antibody responses (except those of the IgE subclass) are regulated mainly by IL-4 operating through the type I IL-4R.

IL-4 and IL-13 are also key inducers of AAM $\phi \mathrm{s}^{11}$, which are believed to regulate antiparasite immunity 37 , wound healing 11 , fibrosis ${ }^{38}$, asthma ${ }^{39}$, allergic inflammation 40 and several other $\mathrm{T}_{\mathrm{H}} 2$ disorders ${ }^{38}$. Studies of mice with macrophage-specific IL-4R $\alpha$ deficiency have confirmed that IL-4R $\alpha$ is essential for AAM $\phi$ development ${ }^{26}$. Our in vitro studies showed that IL-13 exclusively exploited the type II IL-4R to promote AAM $\phi$ development, whereas IL-4 used both type I and type II IL-4 receptors. It has been shown that AAM $\phi$ s are critical for survival during the acute period of $S$. mansoni infection ( $8-9$ weeks $)^{41}$. However, the specific contribution of the type I IL-4R versus the type II IL-4R in the development of this early protective response has remained unclear, as both signaling pathways are effectively 'knocked out' in LysMCre-Ill4ra-/flox mice, which have deletion of IL-4R specifically in macrophages and neutrophils. Our results with $I l 13 \mathrm{ral}^{-1-}$ mice indicated that the type I IL-4R is sufficient for granuloma formation and protection during $S$. mansoni infection, even after high-dose challenge with the parasite. Unexpectedly, even though type II IL-4R signaling can facilitate the development of AAM $\phi$ s in vitro, the type II receptor was dispensable for AAM $\phi$ development in vivo. Indeed, several phenotypic markers of AAM $\phi$ s were highly induced in the livers of infected $I l 13 \mathrm{raI}^{+/+}$and $I l 13 \mathrm{ral}^{-/-}$mice, which suggested that the type I IL-4R is sufficient for AAM $\phi$ development in vivo.

In addition to regulating survival during $S$. mansoni infection, AAM $\phi$ s have been postulated to regulate tissue fibrogenesis 42 and mediate protection against gastrointestinal nematode parasites ${ }^{37}$. Ill3 $\mathrm{ral}^{-1-}$ mice were an ideal model with which to examine the function of IL-4and IL-13-driven type II IL-4R-dependent signaling in the development of fibrosis and antihelminth immunity, as type I IL-4R signaling remained intact. Unexpectedly, although the S. mansoni-infected $I l 13 \mathrm{ral}^{-1-}$ mice developed exacerbated $\mathrm{T}_{\mathrm{H}} 2$ responses and AAM $\phi$ development seemed normal by several criteria, liver fibrosis was considerably less in the absence of IL-13R $\alpha$, which we confirmed by hydroxyproline assay, liver microscopy and quantitative RT-PCR analysis of several extracellular matrix-related genes. In addition, Ill3ral ${ }^{-1-}$ mice were also highly susceptible to $N$. brasilenisis infection, again despite developing strong $\mathrm{T}_{\mathrm{H}} 2$ and $\mathrm{AAM} \phi$ responses. Thus, our data show that the type II IL-4R functions as the critical signaling mechanism for the development of fibrosis and antihelminth immunity. In addition, they suggest that the type I IL-4R and AAM $\phi$ s are less important in these processes than hypothesized before. These observations suggest that fibroblasts and other type II IL-4R-expressing cells are probably the key regulators of fibrosis.

Whereas 'pan-IL-4R-defective' mice $\left(I l 4^{-/-},{I l 4 r a 1^{-/-}}^{-}\right.$and LysMCre-Il4ral $\left.I^{-/ \text {flox }}\right)$ are highly susceptible to toxic death during $S$. mansoni infection 26,27 , deletion of the type II IL-4R provided a long-lasting protective effect. Thus, these data demonstrate that the type I IL- $4 \mathrm{R}$ is host protective, whereas the type II IL-4R serves a mainly pathogenic function during chronic schistosomiasis. Notably, although the profibrotic cytokine TGF- $\beta 1$ has been suggested to be a mediator of IL-13-driven fibrosis, 9,43 , we noted greater production of TGF- $\beta 1$ and MMP9 but much less fibrosis in $1113 \mathrm{ral}^{-1-}$ mice. $I 113 \mathrm{ra} 2 \mathrm{mRNA}$ expression was also lower in Il13ral ${ }^{-1-}$ mice, suggesting that their TGF- $\beta 1$ response was independent of both IL-13R $\alpha 1$ and IL-13R $\alpha 2$-dependent signaling 9 . These findings suggest that the development of fibrosis in schistosomiasis is dependent on the type II IL-4R.

Although our in vivo studies indicated that the type II IL-4R was not critically involved in the expression of genes associated AAM $\phi$ s, including Argl, some genes were highly dependent 
on the type II signaling pathway, including $C c l 11, C c l a 3$ and Muc5ac. These findings suggest that some IL-4- and IL-13-regulated genes are more dependent on type II IL-4R-mediated signaling than are others. Differences in the expression of type I and type II IL-4 receptors on distinct cell populations (macrophages, epithelial cells and so on) may explain this variability. We also found that allergen-induced airway hyperreactivity and mucus production were almost completely dependent on the type II IL-4R. In these experiments, allergen-sensitized Ill3 $\mathrm{ral}^{-1-}$ mice developed stronger $\mathrm{T}_{\mathrm{H}} 2$ responses and upregulated Argl mRNA expression in tissues, as noted in our infection studies. However, airway hyperreactivity and mucus production were completely abrogated. Arginase 1 has been shown to be involved in asthma pathogenesis 39,44 . Our findings suggest that arginase 1 and the type I IL-4R are insufficient for the development of airway hyperreactivity and mucus hyperplasia and that additional factors induced by the type II IL-4R are required.

In summary, our results suggest that the type II IL-4R seems to be involved in the activation of important mesenchymal cells such as fibroblasts and epithelial cells, which contribute to the development of chronic morbidity and mortality in schistosomiasis and in allergic asthma. A study has suggested that AAM $\phi$ s are beneficial in the treatment of type 2 diabetes 45 . Thus, our findings suggest that for some chronic diseases, it may be more advantageous to target the pathogenic type II IL-4R while leaving the type I IL-4R (dominant AAM $\phi$-inducing) pathway intact.

\section{METHODS}

\section{Generation of II13ra1 ${ }^{-/-}$mice}

VelociGene technology was used to generate the $1113 \mathrm{ral}^{-/-}$mice ${ }^{10}$ (Supplementary Fig. 1a). Heterozygous female offspring were repeatedly backcrossed to the C57BL/6 and BALB/c backgrounds. Because the $1113 \mathrm{ral}$ gene is located on the $\mathrm{X}$ chromosome, all male offspring carry either the mutant $(50 \%)$ or wild-type (50\%) allele. DNA obtained from tail tissue was genotyped (primers, Supplementary Table 3 online). Unless otherwise specified, all experiments used male wild-type and mutant littermates at the $\mathrm{N}_{8}$ backcross on the BALB/c background. Mice were housed in a specific pathogen-free animal facility at National Institute of Allergy and Infectious Diseases. All experimental protocols were approved by the animal care and use committee of the National Institute of Allergy and Infectious Diseases.

\section{Parasites and experimental infections}

Mice were infected percutaneously with about 35 S. mansoni cercariae as described 46 .

Schistosome experiments used mice of generations $\mathrm{N}_{4}-\mathrm{N}_{8}$, with appropriate littermate controls of the same generation. Mice of these generations were indistinguishable in terms of each phenotype examined. $N$. brasiliensis larvae (L3) were prepared as described ${ }^{47}$. Wild-type and mutant littermates $\left(\mathrm{N}_{8} ; \mathrm{C} 57 \mathrm{BL} / 6\right.$ background) were inoculated by subcutaneous injection of $500 \mathrm{~L} 3$.

\section{Hepatic leukocyte isolation}

About $200 \mathrm{mg}$ of granulomatous liver was disrupted into a single-cell suspension by being ground through a 100- $\mu$ m nylon mesh. Leukocytes were separated on a $34 \%$ (vol/vol) Percoll gradient ( $350 \mathrm{~g}$ for $20 \mathrm{~min}$ ). After being washed twice in RPMI medium, liver leukocytes were treated for $2 \mathrm{~min}$ with $2 \mathrm{ml}$ ACK (ammonium chloride-potassium bicarbonate) lysis buffer to lyse erythrocytes. 


\section{Intracellular cytokine staining}

Leukocytes isolated from granuloma or mesenteric lymph nodes were stimulated for $3 \mathrm{~h}$ with phorbol 12-myristate 13-acetate $(10 \mathrm{ng} / \mathrm{ml})$, ionomycin $(1 \mu \mathrm{g} / \mathrm{ml})$ and brefeldin A $(10 \mu \mathrm{g} / \mathrm{ml})$. Cells surfaces were stained with phycoerythrin-indodicarbocyanine-conjugated antibody to $\mathrm{CD} 4$ (anti-CD4; H129.19), were fixed for $20 \mathrm{~min}$ at $25^{\circ} \mathrm{C}$ in $2 \%$ (wt/vol) formaldehyde, were made permeable for $30 \mathrm{~min}$ with $0.1 \%$ saponin buffer and were further stained with fluorescein isothiocyanate-conjugated anti-IFN- $\gamma$ (XMG1.2) phycoerythrin-conjugated anti-IL-13 (C531; Centocor), Alexa Fluor 647-conjugated anti-IL-4 (11B11) and allophycocyanin-conjugated anti-IL-5 (TRFK5) before being analyzed on a FACSCalibur (Beckton Dickinson). Antibodies were from BD Pharmingen except where noted otherwise.

\section{RNA isolation and real-time PCR}

About $100 \mathrm{mg}$ of liver tissue was preserved at $-80{ }^{\circ} \mathrm{C}$ in $500 \mu \mathrm{l}$ of RNAlater (Ambion). The sample was homogenized in $1 \mathrm{ml}$ TRIzol reagent (Invitrogen) and total RNA was extracted and analyzed by real-time PCR as described ${ }^{29}$. Primers were designed with Primer Express software (version 2.0; Applied Biosystems), PrimerBank (http://pga.mgh.harvard.edu/primerbank/) or ProbeFinder (version 2.3; https://www.roche-applied-science.com/sis/rtpcr/upl/adc.jsp). Primers for hypoxanthine guanine phosphoribosyl transferase, IL-4, IL-13, IL-10 (ref. 42), IL-13R $\alpha 2$ (ref. 8), YM1, FIZZ1 and IFN- $\gamma^{48}$ have been published (full list of primers, Supplementary Table 3).

\section{Enzyme-linked immunosorbent assay}

Immulon 2HB plates (Thermo) were coated overnight with SEA (10 $\mu \mathrm{g} / \mathrm{ml}$ in PBS). After plates were blocked with $5 \%$ (wt/vol) nonfat dry milk (Carnation), serum was added at various dilutions beginning with a 1:10 dilution. The following secondary antibodies (Southern Biotech) were used for the detection of the corresponding isotypes: anti-IgG1 (H143.225.8), anti-IgG2b (LO-MG2b), anti-IgG3 (LO-MG3), anti-IgA (11-44.2), anti-IgE (23G3) and anti$\operatorname{IgM}(1 \mathrm{~B} 4 \mathrm{~B} 1)$. Total serum IgE was measured with capture antibody to mouse $\operatorname{IgE}$ (R35-72) and biotinylated detection antibody to mouse $\operatorname{IgE}(\mathrm{R} 35-118)$, with a recombinant IgE standard curve (27-74).

\section{Fibrosis, histopathology and $\beta$-galactosidase staining}

Tissue were fixed in Bouin-Hollande fixative and were embedded in paraffin for sectioning. Sizes of hepatic granulomas and composition of lung inflammation were determined on histological sections stained with Wright's Giemsa stain as described ${ }^{29}$. Hepatic collagen was measured as hydroxyproline after hydrolysis of $200 \mathrm{mg}$ liver in $5 \mathrm{ml}$ of $6 \mathrm{~N} \mathrm{HCl}$. Goblet cells were stained with Alcian blue-periodic acid Schiff and were assigned scores of 1 through 4, where ' 0 ' is no PAS ${ }^{+}$staining and ' 4 ' is the maximum staining noted. A published protocol was used for $\beta$-galactosidase staining 49 . The same person assigned scores for all histological features and had no knowledge of the experimental design.

\section{Immunoblot}

Tyrosine-phosphorylated STAT6 were measured by immunoblot as described ${ }^{50}$. After cytokine treatment, cells were washed three times with Dulbecco's PBS and whole-cell lysates were prepared. Total STAT6 protein was immunoprecipitated with rabbit anti-STAT6 (SC-621; Santa Cruz Biotechnology). Immunoprecipitated proteins were resolved by $8 \%$ SDSPAGE (Invitrogen) and then were transferred to polyvinylidene difluoride membranes. Tyrosine-phosphorylated STAT6 or total STAT6 was visualized by enhanced chemiluminescence with rabbit antibody to STAT6 phosphorylated at Tyr641 (93645; Cell Signaling Technology) or rabbit anti-STAT6, respectively. 


\section{Macrophage and fibroblast cultures}

These cultures are described in the Supplementary Methods online.

\section{Arginase activity and nitrite assays}

BMDMs or thioglycollate-elicited macro-phages (day 4) were cultured in 48-well tissue culture plates and were stimulated with IL-4 or IL-13 (20 ng/ml). After being stimulated, cells were washed with PBS and were lysed with $0.1 \%$ (wt/vol) Triton X-100 containing protease inhibitor (Roche Diagnostics). Lysates were transferred to a 96-well PCR plate and were incubated for $10 \mathrm{~min}$ at $55^{\circ} \mathrm{C}$ with $10 \mathrm{mM} \mathrm{MnCl}_{2}$ and $50 \mathrm{mM}$ Tris $\mathrm{HCl}, \mathrm{pH} 7.5$, for enzyme activation. Then, $25 \mu 1$ lysate was removed and was added to $25 \mu 1$ of $1 \mathrm{M}$ arginine, $\mathrm{pH}$ 9.7, in a new PCR plate, followed by incubation for $20 \mathrm{~h}$ at $37^{\circ} \mathrm{C}$. A portion $(5 \mu \mathrm{l})$ of each sample was added in duplicate to a 96-well enzyme-linked immunosorbent assay plate along with $5 \mu \mathrm{l}$ of each standard, diluted in the same assay conditions, beginning with $100 \mathrm{mg} / \mathrm{dl}$. The urea determination reagent from the BioAssay Systems Quantichrome Urea Assay Kit was used according to the manufacturer's protocol. The concentration of nitrite in culture supernatants was determined by spectrophotometry with the Griess reagent.

\section{Allergic airway inflammation and hyperreactivity}

Mice were primed and boosted by intraperitoneal injection of $10 \mu \mathrm{g}$ SEA in PBS on days 0 and 7, respectively. On days 14, 16 and 18, SEA-primed mice were anesthetized with a ketamine-xylazine 'cocktail' and were challenged by intratracheal instillation of $10 \mu \mathrm{g}$ of SEA in $30 \mu \mathrm{l}$ PBS. Then, $24 \mathrm{~h}$ after the last challenge, the airway hyperreactivity of unrestrained mice in response to aerosolized methacholine (3-25 mg/ml in PBS; Sigma-Aldrich) was measured by noninvasive whole-body plethysmography (Buxco systems). Each dose of methacholine was aerosolized for $2 \mathrm{~min}$, followed by $4 \mathrm{~min}$ of data collection during which enhanced-pause measurements were collected and averaged for the entire dose period. Mice were killed by pentobarbital overdose and broncholveoloar lavage was done with PBS and an Insyte venous catheter (BD) to cannulate the trachea.

\section{Statistics}

All data were analyzed with Prism (Version 4; GraphPad). Data were considered statistically significant for $P$ values less than 0.05 , obtained with a two-tailed $t$-test.

\section{Supplementary Material}

Refer to Web version on PubMed Central for supplementary material.

\section{ACKNOWLEDGMENTS}

We thank R. Thompson, S. White and the animal care technicians for technical assistance; F. Lewis and the Biomedical Research Institute for S. mansoni cercariae; and M. Karow (Regeneron) for discussions. Supported by the intramural research program of the National Institutes of Health-National Institute of Allergy and Infectious Diseases, and Regeneron.

\section{References}

1. Finkelman FD, et al. Interleukin-4-and interleukin-13-mediated host protection against intestinal nematode parasites. Immunol. Rev 2004;201:139-155. [PubMed: 15361238]

2. Padilla J, et al. IL-13 regulates the immune response to inhaled antigens. J. Immunol 2005;174:80978105. [PubMed: 15944318]

3. Grunig G, et al. Roles of interleukin-13 and interferon- $\gamma$ in lung inflammation. Chest 2002;121:88S. [PubMed: 11893713] 
4. Wills-Karp M, et al. Interleukin-13: central mediator of allergic asthma. Science 1998;282:2258-2261. [PubMed: 9856949]

5. Chiaramonte MG, Donaldson DD, Cheever AW, Wynn TA. An IL-13 inhibitor blocks the development of hepatic fibrosis during a T-helper type 2-dominated inflammatory response. J. Clin. Invest 1999;104:777-785. [PubMed: 10491413]

6. Wynn TA. IL-13 effector functions. Annu. Rev. Immunol 2003;21:425-456. [PubMed: 12615888]

7. Murata T, Taguchi J, Puri RK, Mohri H. Sharing of receptor subunits and signal transduction pathway between the IL-4 and IL-13 receptor system. Int. J. Hematol 1999;69:13-20. [PubMed: 10641437]

8. Chiaramonte MG, et al. Regulation and function of the interleukin 13 receptor $\alpha 2$ during a $\mathrm{T}$ helper cell type 2-dominant immune response. J. Exp. Med 2003;197:687-701. [PubMed: 12642601]

9. Fichtner-Feigl S, Strober W, Kawakami K, Puri RK, Kitani A. IL-13 signaling through the IL-13 $\alpha 2$ receptor is involved in induction of TGF- $\beta 1$ production and fibrosis. Nat. Med 2006;12:99-106. [PubMed: 16327802]

10. Valenzuela DM, et al. High-throughput engineering of the mouse genome coupled with highresolution expression analysis. Nat. Biotechnol 2003;21:652-659. [PubMed: 12730667]

11. Gordon S. Alternative activation of macrophages. Nat. Rev. Immunol 2003;3:23-35. [PubMed: 12511873]

12. Richter A, et al. The contribution of interleukin (IL)-4 and IL-13 to the epithelial-mesenchymal trophic unit in asthma. Am. J. Respir. Cell Mol. Biol 2001;25:385-391. [PubMed: 11588018]

13. Wang IM, Lin H, Goldman SJ, Kobayashi M. STAT-1 is activated by IL-4 and IL-13 in multiple cell types. Mol. Immunol 2004;41:873-884. [PubMed: 15261459]

14. Doucet C, Giron-Michel J, Canonica GW, Azzarone B. Human lung myofibro-blasts as effectors of the inflammatory process: the common receptor $\gamma$ chain is induced by Th2 cytokines, and CD40 ligand is induced by lipopolysaccharide, thrombin and TNF- $\alpha$. Eur. J. Immunol 2002;32:2437-2449. [PubMed: 12207328]

15. Lordan JL, et al. Cooperative effects of Th2 cytokines and allergen on normal and asthmatic bronchial epithelial cells. J. Immunol 2002;169:407-414. [PubMed: 12077271]

16. Zurawski G, de Vries JE. Interleukin 13 elicits a subset of the activities of its close relative interleukin 4. Stem Cells 1994;12:169-174. [PubMed: 7911047]

17. Lai YH, Mosmann TR. Mouse IL-13 enhances antibody production in vivo and acts directly on B cells in vitro to increase survival and hence antibody production. J. Immunol 1999;162:78-87. [PubMed: 9886372]

18. Punnonen J, de Vries JE. IL-13 induces proliferation, Ig isotype switching, and Ig synthesis by immature human fetal B cells. J. Immunol 1994;152:1094-1102. [PubMed: 7507958]

19. Guo L, et al. Disrupting Ill3 impairs production of IL-4 specified by the linked allele. Nat. Immunol 2001;2:461-466. [PubMed: 11323701]

20. McKenzie GJ, et al. Impaired development of Th2 cells in IL-13-deficient mice. Immunity 1998;9:423-432. [PubMed: 9768762]

21. McKenzie AN, et al. Interleukin 13, a T-cell-derived cytokine that regulates human monocyte and B-cell function. Proc. Natl. Acad. Sci. USA 1993;90:3735-3739. [PubMed: 8097324]

22. Li L, et al. IL-4 utilizes an alternative receptor to drive apoptosis of Th1 cells and skews neonatal immunity toward Th2. Immunity 2004;20:429-440. [PubMed: 15084272]

23. Hoffmann KF, et al. Disease fingerprinting with cDNA microarrays reveals distinct gene expression profiles in lethal type 1 and type 2 cytokine-mediated inflammatory reactions. FASEB J 2001;15:2545-2547. [PubMed: 11641263]

24. Brunet LR, Finkelman FD, Cheever AW, Kopf MA, Pearce EJ. IL-4 protects against TNF- $\alpha$-mediated cachexia and death during acute schistosomiasis. J. Immunol 1997;159:777-785. [PubMed: 9218595]

25. Fallon PG, Richardson EJ, McKenzie GJ, McKenzie AN. Schistosome infection of transgenic mice defines distinct and contrasting pathogenic roles for IL-4 and IL-13: IL-13 is a profibrotic agent. J. Immunol 2000;164:2585-2591. [PubMed: 10679097] 
26. Herbert DR, et al. Alternative macrophage activation is essential for survival during schistosomiasis and downmodulates T helper 1 responses and immunopathology. Immunity 2004;20:623-635. [PubMed: 15142530]

27. Jankovic D, et al. Schistosome-infected IL-4 receptor knockout (KO) mice, in contrast to IL-4 KO mice, fail to develop granulomatous pathology while maintaining the same lymphokine expression profile. J. Immunol 1999;163:337-342. [PubMed: 10384133]

28. Urban JF Jr, et al. IL-13, IL-4R $\alpha$, and Stat6 are required for the expulsion of the gastrointestinal nematode parasite Nippostrongylus brasiliensis. Immunity 1998;8:255-264. [PubMed: 9492006]

29. Wilson MS, et al. IL-13R $\alpha 2$ and IL-10 coordinately suppress airway inflammation, airwayhyperreactivity, and fibrosis in mice. J. Clin. Invest 2007;117:2941-2951. [PubMed: 17885690]

30. McKenzie GJ, Fallon PG, Emson CL, Grencis RK, McKenzie AN. Simultaneous disruption of interleukin (IL)-4 and IL-13 defines individual roles in T helper cell type 2-mediated responses. J. Exp. Med 1999;189:1565-1572. [PubMed: 10330435]

31. Noben-Trauth N, et al. An interleukin 4 (IL-4)-independent pathway for CD4 ${ }^{+} \mathrm{T}$ cell IL-4 production is revealed in IL-4 receptor-deficient mice. Proc. Natl. Acad. Sci. USA 1997;94:10838-10843. [PubMed: 9380721]

32. Kopf M, et al. Disruption of the murine IL-4 gene blocks Th2 cytokine responses. Nature 1993;362:245-248. [PubMed: 8384701]

33. Herrick CA, Xu L, McKenzie AN, Tigelaar RE, Bottomly K. IL-13 is necessary, not simply sufficient, for epicutaneously induced Th2 responses to soluble protein antigen. J. Immunol 2003;170:24882495. [PubMed: 12594274]

34. Cocks BG, de Waal Malefyt R, Galizzi JP, de Vries JE, Aversa G. IL-13 induces proliferation and differentiation of human B cells activated by the CD40 ligand. Int. Immunol 1993;5:657-663. [PubMed: 7688562]

35. Punnonen J, et al. Interleukin 13 induces interleukin 4-independent IgG4 and IgE synthesis and CD23 expression by human B cells. Proc. Natl. Acad. Sci. USA 1993;90:3730-3734. [PubMed: 8097323]

36. Emson CL, Bell SE, Jones A, Wisden W, McKenzie AN. Interleukin (IL)-4-independent induction of immunoglobulin $(\mathrm{Ig}) \mathrm{E}$, and perturbation of $\mathrm{T}$ cell development in transgenic mice expressing IL-13. J. Exp. Med 1998;188:399-404. [PubMed: 9670052]

37. Anthony RM, et al. Memory $\mathrm{T}_{\mathrm{H}} 2$ cells induce alternatively activated macrophages to mediate protection against nematode parasites. Nat. Med 2006;12:955-960. [PubMed: 16892038]

38. Wynn TA. Fibrotic disease and the $\mathrm{T}_{\mathrm{H}} 1 / \mathrm{T}_{\mathrm{H}} 2$ paradigm. Nat. Rev. Immunol 2004;4:583-594. [PubMed: 15286725]

39. Zimmermann N, et al. Dissection of experimental asthma with DNA microarray analysis identifies arginase in asthma pathogenesis. J. Clin. Invest 2003;111:1863-1874. [PubMed: 12813022]

40. Loke P, MacDonald AS, Robb A, Maizels RM, Allen JE. Alternatively activated macrophages induced by nematode infection inhibit proliferation via cell-to-cell contact. Eur. J. Immunol 2000;30:2669-2678. [PubMed: 11009101]

41. Herbert DR, et al. Alternative macrophage activation is essential for survival during schistosomiasis and downmodulates T helper 1 responses and immunopathology. Immunity 2004;20:623-635. [PubMed: 15142530]

42. Hesse M, et al. Differential regulation of nitric oxide synthase- 2 and arginase- 1 by type $1 /$ type 2 cytokines in vivo: granulomatous pathology is shaped by the pattern of L-arginine metabolism. J. Immunol 2001;167:6533-6544. [PubMed: 11714822]

43. Lee CG, et al. Interleukin-13 induces tissue fibrosis by selectively stimulating and activating transforming growth factor $\beta 1$. J. Exp. Med 2001;194:809-821. [PubMed: 11560996]

44. Yang M, et al. Inhibition of arginase I activity by RNA interference attenuates IL-13-induced airways hyperresponsiveness. J. Immunol 2006;177:5595-5603. [PubMed: 17015747]

45. Odegaard JI, et al. Macrophage-specific PPAR $\gamma$ controls alternative activation and improves insulin resistance. Nature 2007;447:1116-1120. [PubMed: 17515919]

46. Mentink-Kane MM, et al. IL-13 receptor $\alpha 2$ down-modulates granulomatous inflammation and prolongs host survival in schistosomiasis. Proc. Natl. Acad. Sci. USA 2004;101:586-590. [PubMed: 14699044] 
47. Katona IM, Urban JF Jr, Scher I, Kanellopoulos-Langevin C, Finkelman FD. Induction of an IgE response in mice by Nippostrongylus brasiliensis: characterization of lymphoid cells with intracytoplasmic or surface IgE. J. Immunol 1983;130:350-356. [PubMed: 6600186]

48. Pesce J, et al. The IL-21 receptor augments Th2 effector function and alternative macrophage activation. J. Clin. Invest 2006;116:2044-2055. [PubMed: 16778988]

49. Adams, NC.; Gale, NW. Mammalian and Avian Transgenesis-New Approaches. Pease, S.; Lois, C., editors. Berlin-Heidelberg: Springer; 2006. p. 131-172.

50. Dickensheets H, Venkataraman C, Schindler U, Donnelly R. Interferons inhibit activation of STAT6 by interleukin 4 in human monocytes by inducing SOCS-1 gene expression. Proc. Natl. Acad. Sci. USA 1999;96:10800-10805. [PubMed: 10485906] 


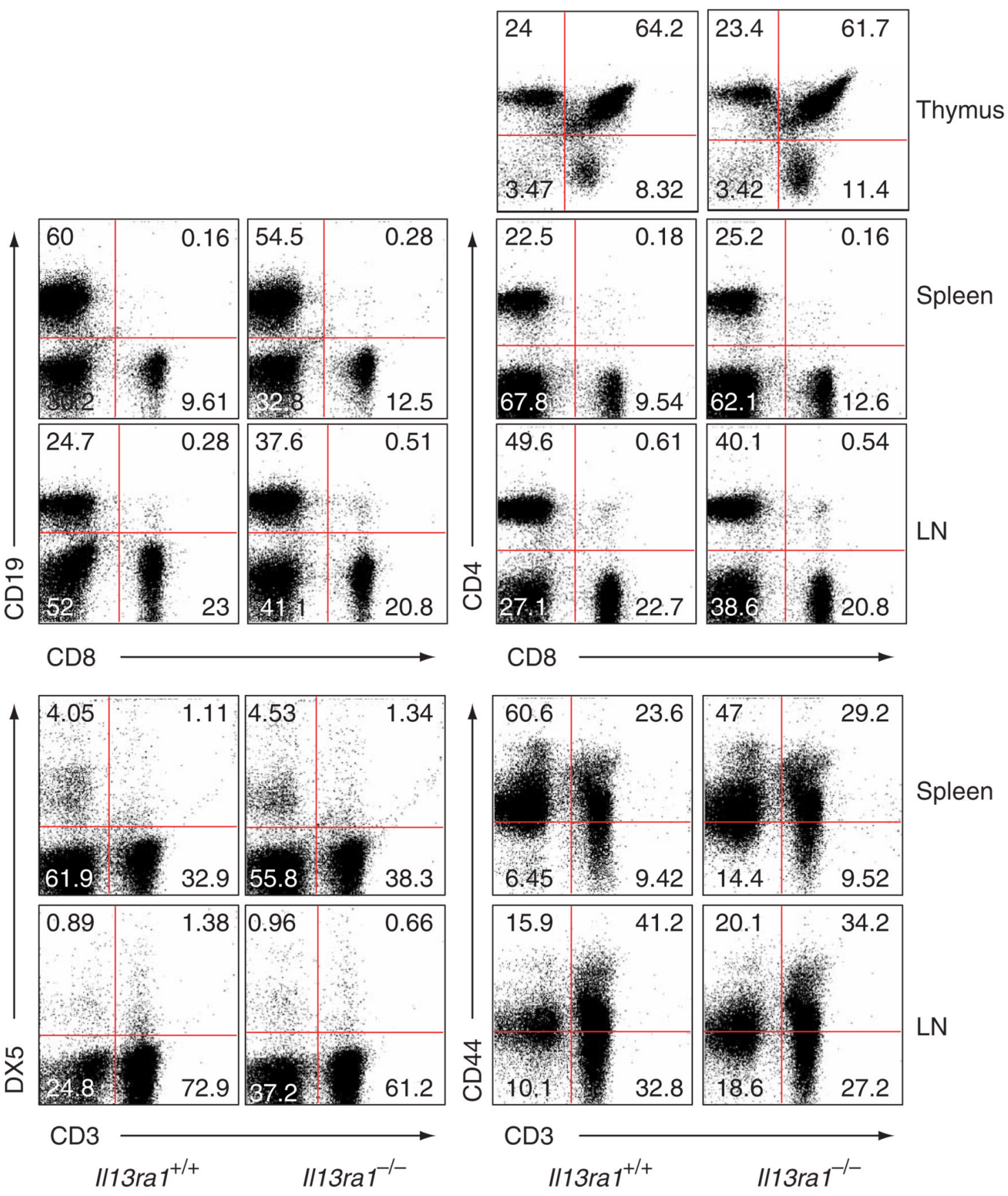

Figure 1.

Characterization of $1113 \mathrm{ral}^{-/-}$mice. Flow cytometry of single-cell suspensions of homogenized thymus, spleen and lymph nodes (LN) from naive $1113 \mathrm{ral}^{+/+}$and $1113 \mathrm{ral}^{-/-}$ littermates. Lymphocytes are gated based on forward- and side-scatter parameters. Numbers in quadrants indicate percent among lymphocytes. Data are representative of two experiments with two to three mice per group. 

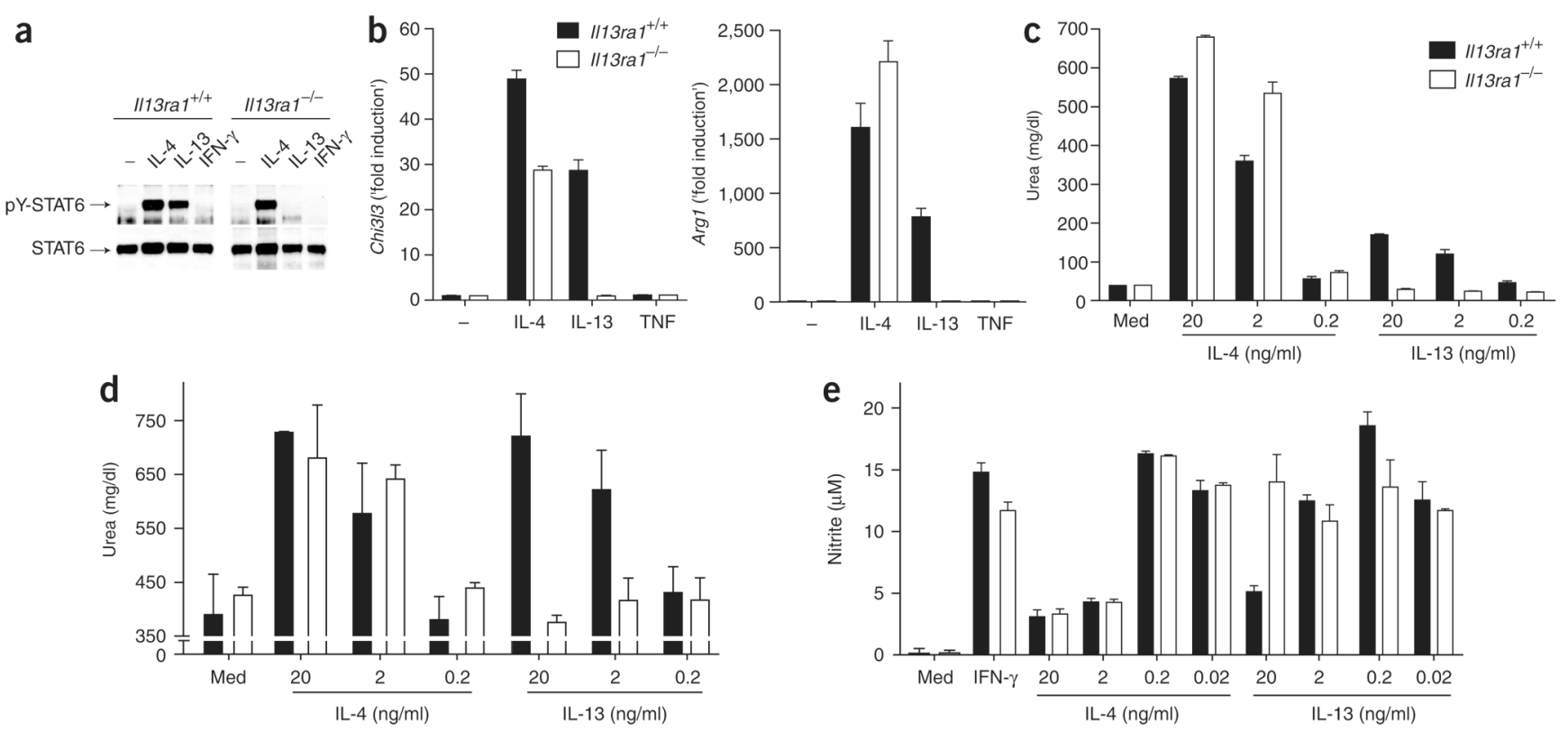

Figure 2.

Macrophages respond to IL-4 but not IL-13 in the absence of type II IL-4 receptor signaling. (a) Immunoprecipitation and immunoblot analysis of STAT6 phosphorylation (pY-STAT6) in $I l 13 \mathrm{ral}^{+/+}$and $I l 13 \mathrm{ral}^{-/-}$BMDMs stimulated for $30 \mathrm{~min}$ at $37^{\circ} \mathrm{C}$ with IL-4, IL-13 or IFN$\gamma(20 \mathrm{ng} / \mathrm{ml})$. (b) Real-time PCR of genes encoding YM1 (Chi3l3) and arginase 1 (Argl) in BMDMs stimulated for $20 \mathrm{~h}$ with IL-4, IL-13 or tumor necrosis factor (TNF; $20 \mathrm{ng} / \mathrm{ml}$ ), presented as 'fold increase' relative to that in unstimulated cells. (c,d) Arginase activity in lysates of BMDMs (c) or thioglycollate-elicited macrophages (d) treated with various concentrations of IL-4 or IL-13 and analyzed after $48 \mathrm{~h}$ by measurement of urea production. (e) Nitric oxide production by thioglycollate-elicited macrophages pretreated for $20 \mathrm{~h}$ with various concentrations of IL- 4 or IL-13, followed by the addition of $200 \mathrm{U}$ IFN- $\gamma$ (to induce synthesis of inducible nitric oxide synthase); supernatants were analyzed $48 \mathrm{~h}$ later for nitrite. Data are representative of two $(\mathbf{a}, \mathbf{c}-\mathbf{b})$ or four $(\mathbf{b})$ independent experiments with similar results (error bars, s.e.m.). 

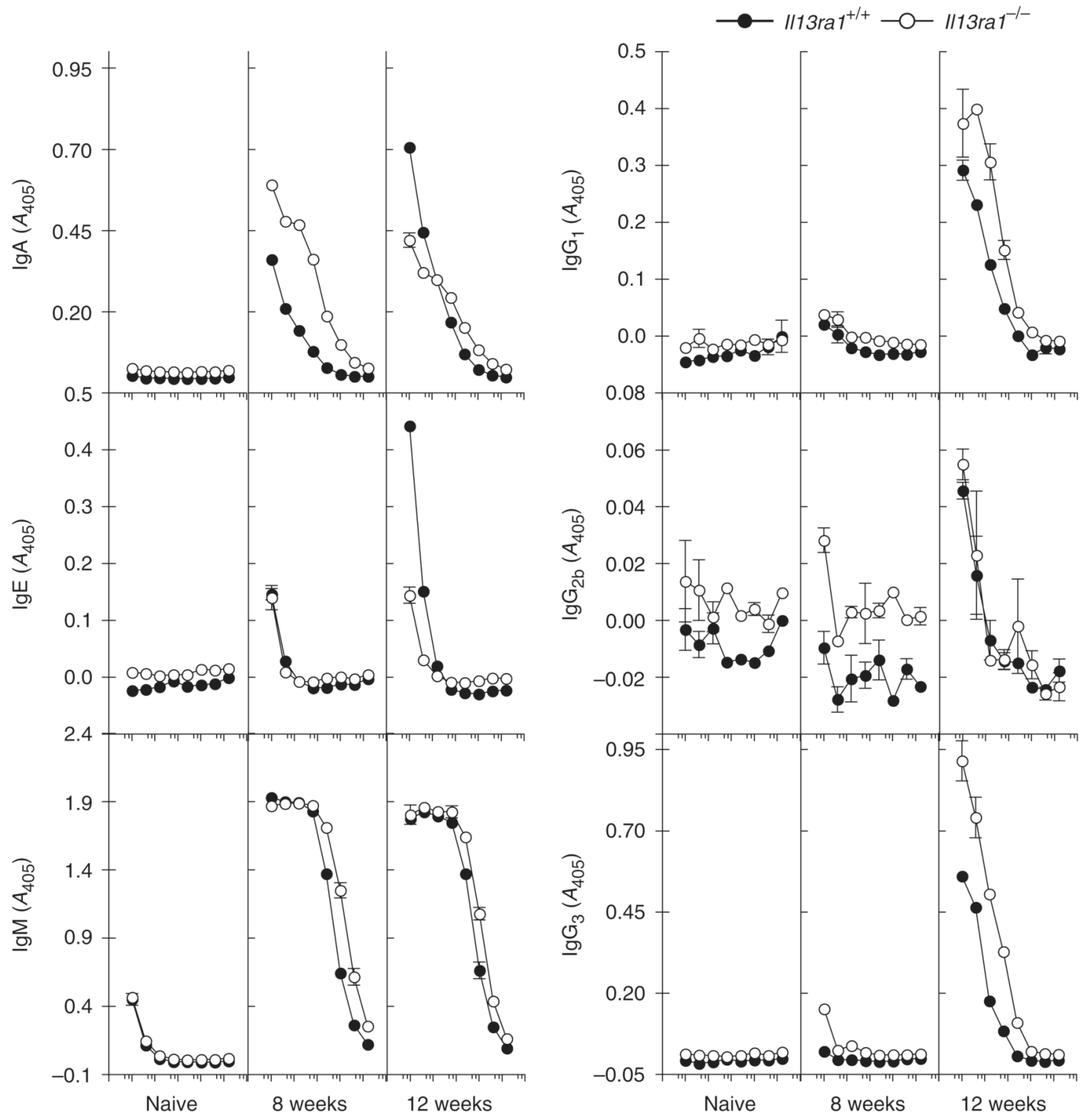

Figure 3.

Serum immunoglobulin production by $I l 13 \mathrm{ral}^{-/-}$mice chronically infected with $S$. mansoni. Enzyme-linked immunosorbent assay of SEA-specific immunoglobulin subclasses in serum from naive mice or mice infected with $S$. mansoni ( $n=5-10$ mice), collected at 8 and 12 weeks after infection and pooled, presented as absorbance at $405 \mathrm{~nm}\left(A_{450}\right)$. Data from one of two similar experiments (error bars, s.e.m.). 

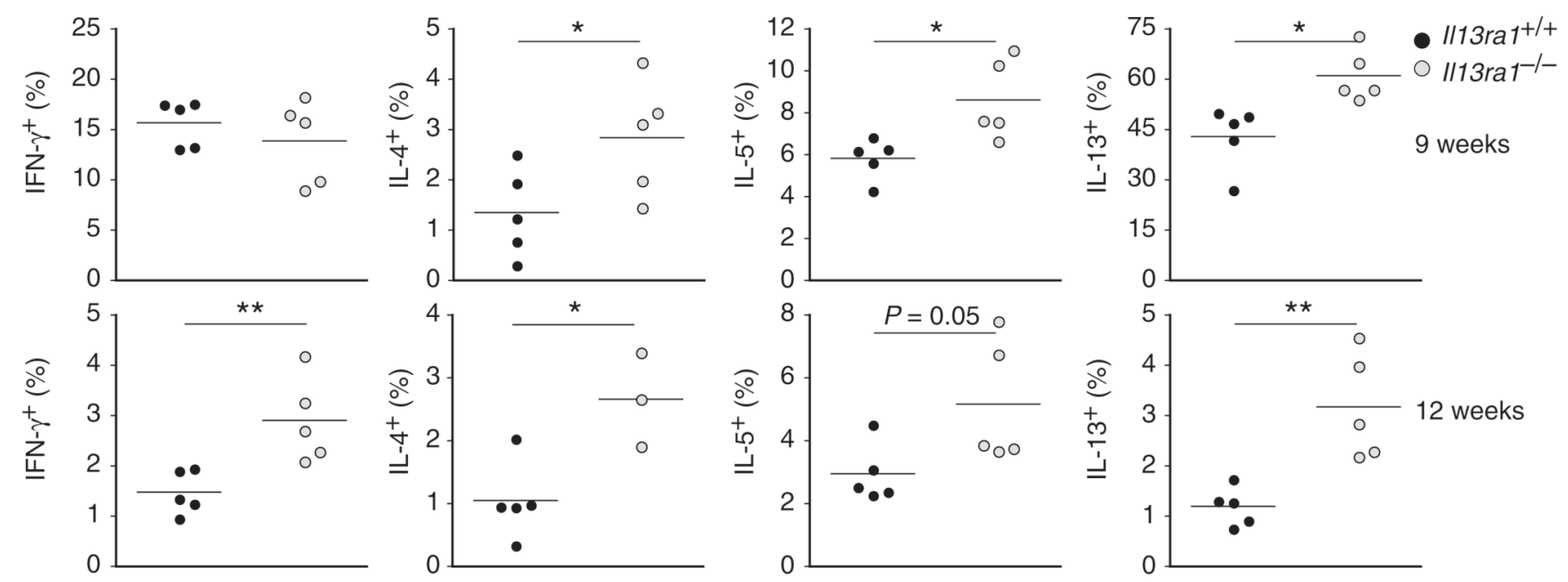

Figure 4.

Cytokine production by liver granuloma-associated lymphocytes after $S$. mansoni infection.

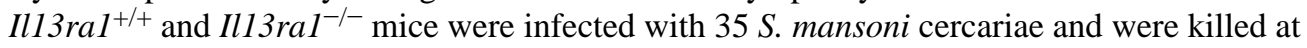
9 and 12 weeks after infection; leukocytes isolated from perfused livers were stimulated for 3 $\mathrm{h}$ with phorbol 12-myristate 13-acetate and ionomycin in the presence of brefeldin A, followed by cytokine-specific antibodies. The frequency of cytokine-producing $\mathrm{CD} 4^{+} \mathrm{T}$ cells was determined for viable cells, identified by forward- and side-scatter parameters. Each dot represents an individual mouse; horizontal bars in the midst of the dots indicate the mean for each group. *, $P<0.05$; **, $P<0.01$. Data are representative of three experiments, one on the $\mathrm{BALB} / \mathrm{c}$ background and two on the C57BL/6 background, which yielded similar results 

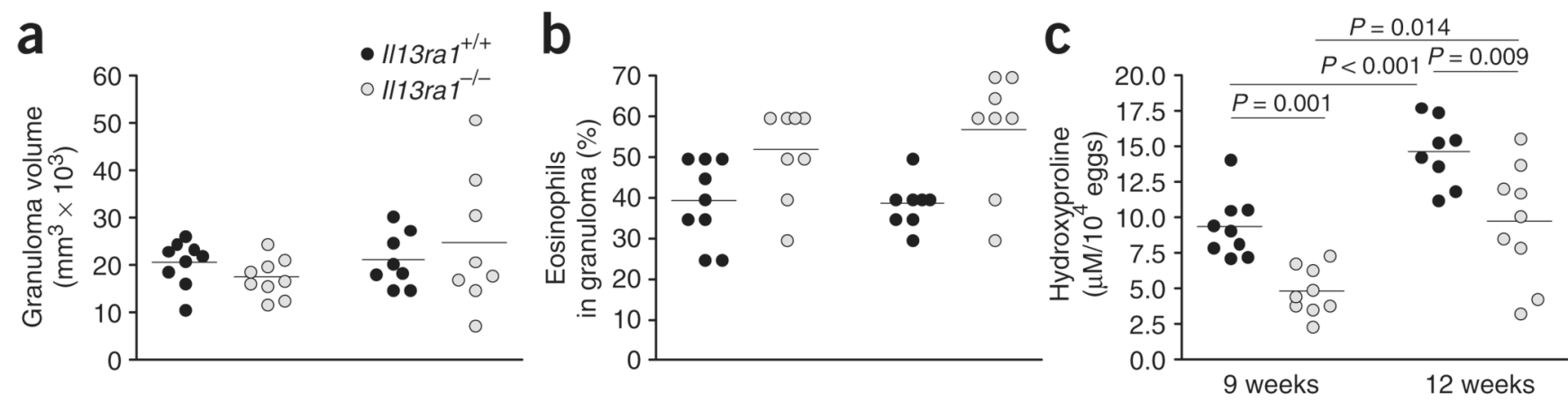

Figure 5.

Attenuated tissue fibrosis in $I l 13 \mathrm{raI}^{-1-}$ mice. Cohorts of $1113 \mathrm{ral}^{+/+}$and $I l 13 \mathrm{raI}^{-1-}$ mice were infected with 35 S. mansoni cercariae and were killed at 9 and 12 weeks after infection. (a) Volume of granulomas around viable eggs measured by microscopy of Giemsa-stained sections of paraffin-embedded liver samples. (b) Percent eosinophils among cells constituting the granuloma, assessed in Giemsa-stained sections. (c) Fibrosis, measured as liver hydroxyproline content and normalized to egg numbers. Each dot represents an individual mouse; small horizontal lines indicate the average for each group. Data are representative of three independent experiments and were reproduced on the BALB/c and C57BL/6 backgrounds 

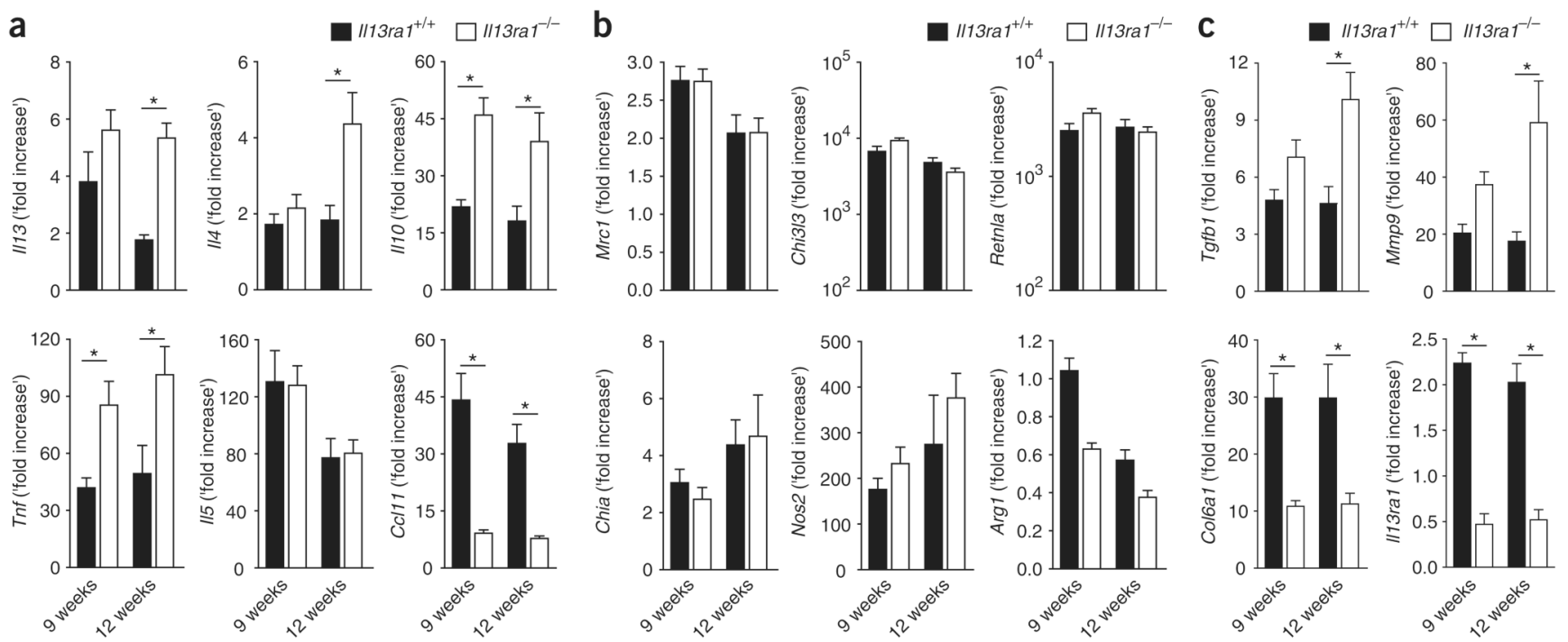

Figure 6.

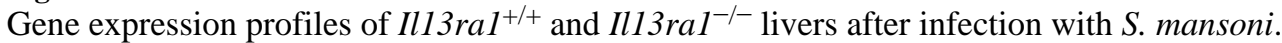
Real-time PCR of liver mRNA from $1 / 13 \mathrm{ral}^{+/+}$and $\mathrm{Ill}_{3} \mathrm{ral}^{-/-}$mice infected with $35 \mathrm{~S}$. mansoni cercariae and killed at 9 and 12 weeks later; expression is presented as the 'fold increase' relative to that in livers of naive mice. (a) Genes encoding cytokines. (b) Genes encoding molecules associated with alternative macrophage activation: mannose receptor (Mrcl), YM1 (Chi3l3), FIZZ1 (Retnla), AMCase (Chia), inducible nitric oxide synthase (Nos2) and arginase 1 ( $\mathrm{Arg} 1)$. (c) Genes encoding molecules involved in extracellular matrix remodeling: TGF- $\beta 1$ (Tgfbl), MMP9 (Mmp9), procollagen VI (Col6al) and IL-13R $\alpha 1$ (Ill3ral). *, $P<0.05$. Data are representative of three experiments, one on the BALB/c background and two on the C57BL/6 background, which yielded similar results 

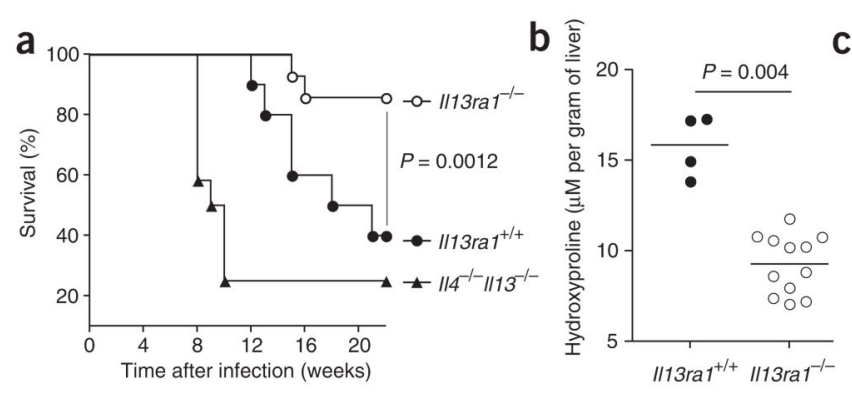

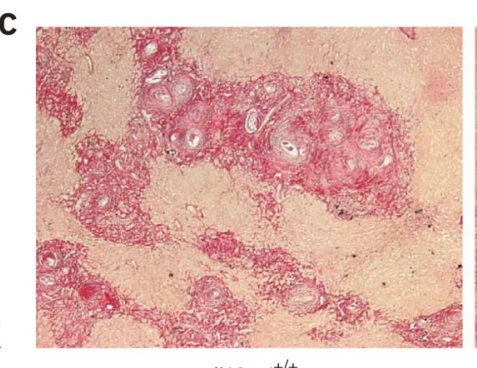

$1 / 13 \mathrm{ra} 1^{+/+}$

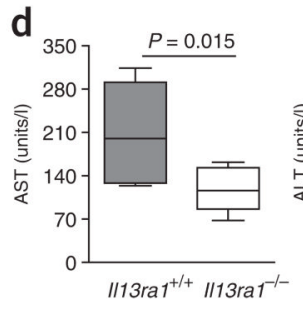

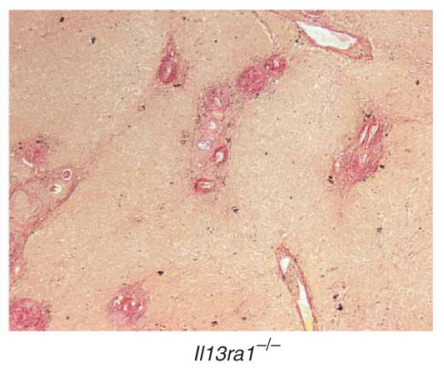
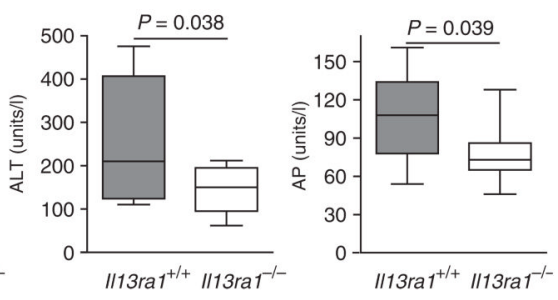

Figure 7.

Type II IL-4R deficiency protects mice from morbidity after S. mansoni infection. Survival and liver analysis of $I l 13 \mathrm{ral}^{+/+}, \mathrm{Ill} 3 \mathrm{ral}^{-/-}$and $\mathrm{Ill}^{-{ }^{-1}} \mathrm{Il4^{-/- }}$ mice ( $n=10-12$ mice per group) infected with 60 S. mansoni cercariae, monitored up to 22 weeks after infection. (a) Survival curves. (b) Hydroxyproline in infected livers at 22 weeks. (c) Collagen content of infected livers, as assessed by microscopy of picrosirius-stained paraffinembedded liver sections at 22 weeks. Original magnification, $\times 5$. (d) Liver function, assessed by measurement of alanine transaminase (ALT), aspartate transaminase (AST) and alkaline phosphatase (AP) in serum at 12 weeks after infection. Data are representative of two independent experiments 


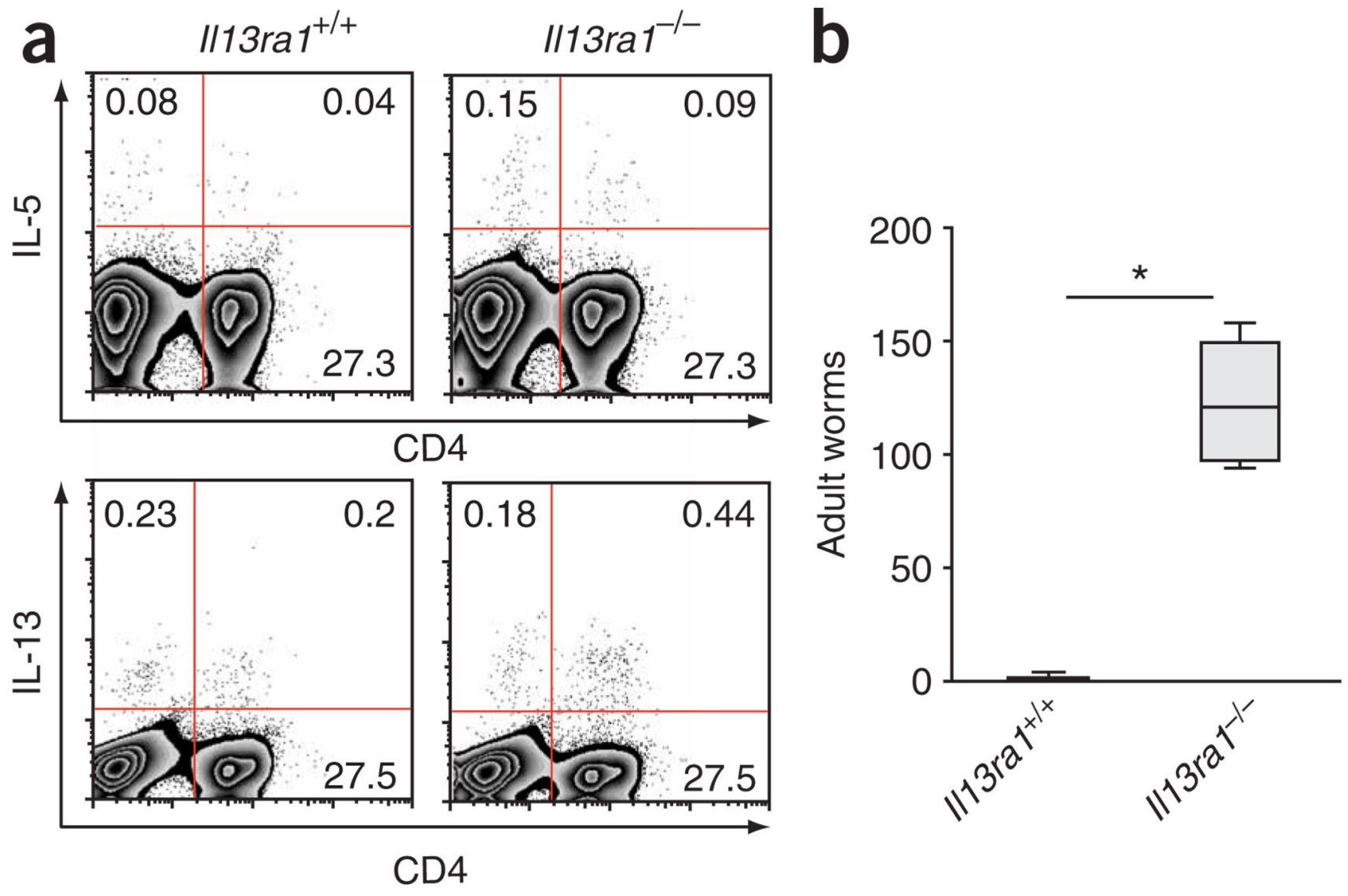

Figure 8.

Impaired expulsion of $N$. brasiliensis in $1 l 13 \mathrm{ral}^{-1-}$ mice. Analysis of $1 l 13 \mathrm{ral}^{+/+}$and Ill3 $\mathrm{ral}^{-/-}$mice ( $n=5$ mice) inoculated subcutaneously with $500 \mathrm{~N}$. brasiliensis L3 and killed on day 12 after infection. (a) Flow cytometry of intracellular IL-5 and IL-13 in mesenteric lymph node cells stimulated for $3 \mathrm{~h}$ ex vivo with phorbol 12-myristate 13-acetate and ionomycin. Density plots are gated on lymphocytes; numbers in quadrants indicate percent cytokine-producing cells among lymphocytes. (b) Adult worm recovery. ${ }^{*}, P=0.0001$. Data are representative of two separate experiments. 

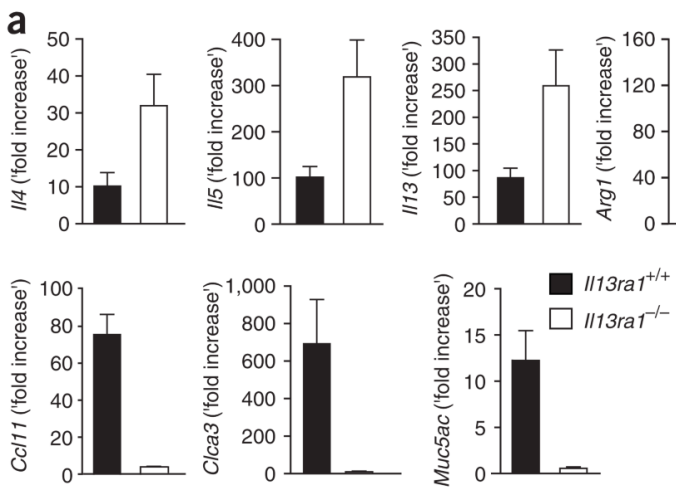

$\stackrel{\Sigma}{3}$

e
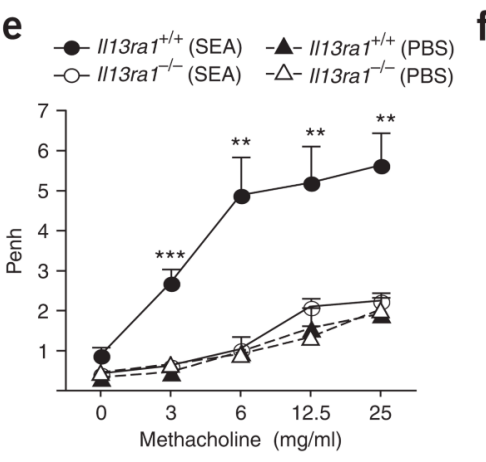
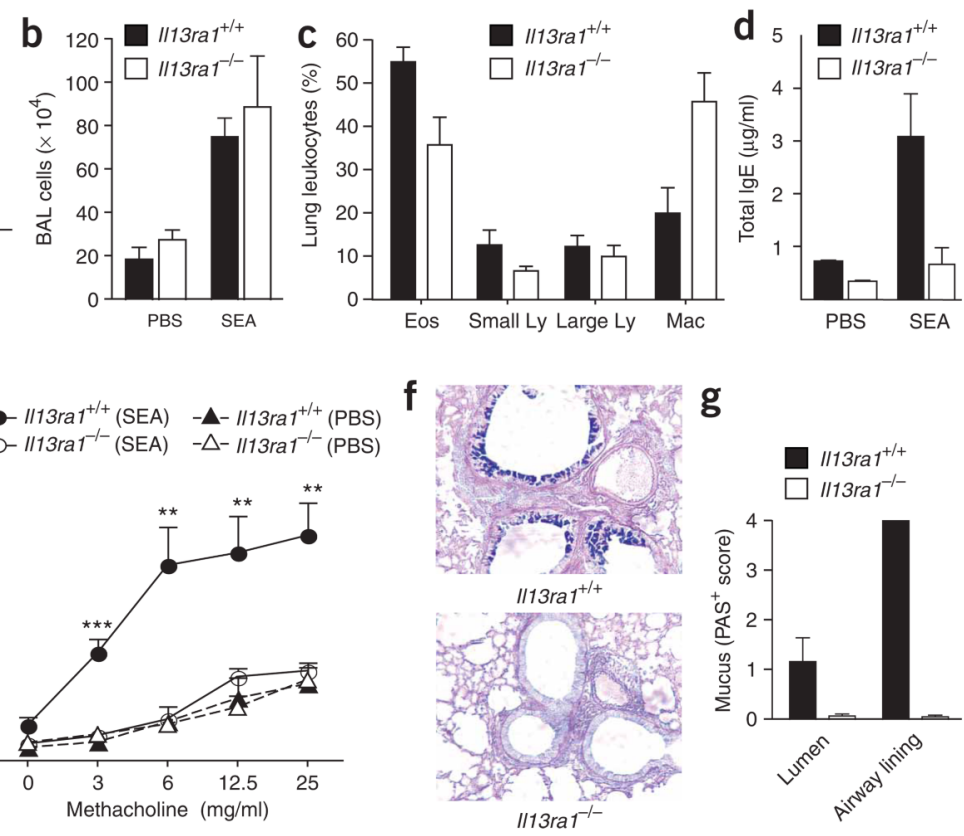

g

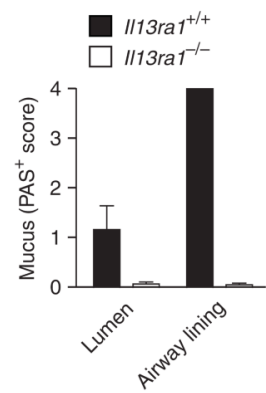

Figure 9.

Protection from allergen-induced airway hyperreactivity in $1113 \mathrm{ral}^{-1-}$ mice. Analysis of

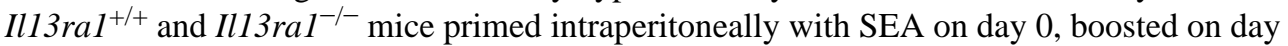
7, challenged intratracheally with SEA or PBS on days 14,16 and 18, and evaluated on day 19. (a) Expression of mRNA transcripts encoding $\mathrm{T}_{\mathrm{H}} 2$ cytokines, eotaxin and mucus molecules in lung tissue relative to expression in PBS controls. (b) Total cellularity of bronchoalveolar lavage (BAL) fluid. (c) Composition of lung leukocyte infiltrates, assessed by microscopy of Giemsa-stained sections of paraffin-embedded lung samples, presented as percent of total leukocytes ( $n=6$ lungs per group). Eos, eosinophils; Ly, lymphocytes; Mac, macrophages. (d) Enzyme-linked immunosorbent assay of total serum IgE. (e) Airway hyperreactivity, as measured by whole-body plethysmography of unrestrained mice exposed to increasing concentration of aerosolized methacholine. Penh, enhanced pause. (f) Mucin staining with Alcian blue-periodic acid Schiff in lungs of SEA-challenged mice. Original magnification, $\times 10$. (g) Mucus production in airway lumen and bronchial walls (airway lining), assigned scores for histology of sections stained with Alcian blue-periodic acid Schiff (PAS ${ }^{+}$score; $n$ $=6$ mice per group). $*, P<0.05$; **, $P<0.01 ; * * *, P<0.005$. Data are from one of two similar experiments with four to seven mice per group. 